\title{
基于能力本位课程开发建设下的人才培养模式的探析一一室 内艺术设计专业为例
}

\author{
钟鹤林 \\ 贵州电子商务职业技术学院 \\ DOI:10.32629/er.v3i9.3162
}

\begin{abstract}
[摘要] 能力本位课程是新时代下, 为改变我国目前的职业教育现状, 通过教育部专家, 外国职教行业专 家, 国内一线老师和企业代表组成的团队,根据我国职业教育特点,分析和探讨,总结和归纳,选用的一种 职业教育课程体系。
\end{abstract}

[关键词] 能力本位; 课程开发; 人才培养

中图分类号：G71 文献标识码：A

\section{1 发展形势下的课程建设}

能力本位课程是基于国外先进的职 业教育理念, 根据我国目前职业教育发 展改革的需要, 由国家教育部职教专家、 各省职业教育专家和各省优秀青年教师 组成的课程开发团队, 提出的一种适用 于我国当下的职业教育的理念, 旨在培 养以能力本位为核心的技能型人才。这 种职业教育新型的模式, 要求不断加强 现代职业教育的改革, 不断提高学生职 业技能水平, 从而使职业教育更好的适 应未来社会发展的需求。在新的形势下, 国家不断提出职业技能人才的战略部署, 以及教育部门出台相关政策和法规, 要 求各院校修改相关人才培养模式和调整 人才培养目标, 更新各专业课程目标、课 时计划和组织教学内容等。

从全球化的职业发展来看, 工业发 展从1.0到 4.0 的跨越, 使不同地区, 不同 经济体制的国家, 经济上都有翻天覆地 的变化, 特别是对人才需求的文化程度 有所不同, 然而, 人才的需求从工业 1.0 的大量需求, 到工业 4.0 的不断递减的趋 势, 这要求不同人才的专业化程度越来 越高, 职业素质也越来越高, 综合职业素 质多元化的发展等。在我国目前的发展 形势来看, 我国正处于工业3.0向4.0迈 进的阶段, 这要求各院校培养的人才在
原来的基础上有所改革, 提出必要的相 关改革及措施, 例如人才职业技能和专 业化程度等方面的需求。

从国家战略来看, 我国正处在积极 的建设各种不同专业的职业院校, 加大 对职业教育的投资和规划, 特别是目前 国务院印发了国发2019[4号]《国家职业 教育改革实施方案》, 奋力办好新时代职 业教育的决策部署和细化为若干的具体 行动等, 这迫切需要对中国职业教育的 改革与创新, 也是机遇与挑战。因此, 能 力本位课程的职业教学体系, 更能适应 当今我国的职业发展需求。

\section{2 课程开发建设}

近年, 由国家教育部职教专家在各 省开展课程体系建设, 分别组织各职教 院校优秀教师开展为期的培训和指导, 集各专业教师的教科研经历, 并结合当 地人才需求和市场导向, 开展能力本位 课程相关建设, 以互联网网络平台为依 托, 根据不同的人才需求和人才定位, 制 定相关的能力本位课程开发建设。首先 从人才培养方案的架构来看, 参照 2015 《中国国家职业分类大典》、2016《国家 职业技能标准》、以及行业 (企业) 实施标 准等, 实行精准对标, 从内容、形式、对 象、教材、评价、师生关系和技能考核 等方面的转变, 从传统的以老师为中心
向以学生为中心的职业教育教学模式的 改革; 其次, 从课程标准的设计来看, 课 程标准主要以人才培养方案为指导, 从 不同的岗位来设置相应的对标, 参照国 家对学生职业的定位标准, 依托行业 (企 业)对职业人才的需求标准等, 来根据具 体情况实施相关的课程设置, 在课程设 置上, 主要以能力本位目标为主、重视实 际项目执行情况、参照学生实际操作过 程评价、师生之间的课堂互动等内容建 立课程项目任务点, 贯穿课堂的技能任 务的时间线和课程项目学生技能的的评 价, 从不同方面来进行; 最后, 要让学生 在做中学, 在做中不断的积累, 同学们通 过能力本位课程项目任务的学习, 在做 中不断的受到老师和同学们的鼓励与支 持, 从而树立学习信心, 从中受到学习的 启发, 挑战不同项目的难度和层次, 培养 自身良好的动手能力和学习习惯。

例如, 室内艺术设计专业不同课程 的开设, 具体以能力本位课程为指导, 开 展不同项目的测评为手段, 指导和鼓励 学生在不同的项目中受到启发, 在不同 的项目中总结相关技能知识, 在不同的 具体项目中让学生对新知识的不断探求, 在项目中激发每一个学生的潜能。例如, 学生在《室内装饰材料与施工工艺》这 门课程中, 在其中设计一个项目, 主要是 
以板材工艺和特点的学习项目, 要求学 生对市场板材的调查。首先, 老师发放一 张能力本位考核测评表格给学生, 表格 的设计由老师完成, 要求学生对几种基 本板材的了解, 表格上要求学生考察过 的板材公司盖一个销售章或者相关部门 章, 并要求独立完成; 其次, 考核测评表 格上要求对不同板材的色泽、纹理、尺 寸、产地、主要用途、裁切工艺方面的 内容等写上相关标准和个人意见; 最后, 收集相关考核测评表格, 老师提供相关 项目测评标准, 学生之间根据老师提出 的项目测评任务点互评得分, 并由老师 审核通过。

紧接着下一个项目的开展, 就可以 是根据学生之间考察的板材市场, 设计 一个造型 (可以为家居, 也可以为墙面、 地面、顶面造型等), 具体做法, 步骤, 施 工规范等, 要求学生提交的造型, 参考相 关过程和结果测评等。

\section{3 具体的实施}

在能力本位课程的推广和实施方面, 需要国家做战略性的支持, 例如国务院 印发了国发2019[4号]《国家职业教育改 革实施方案》, 2015《中国国家职业分类 大典》、2016《国家职业技能标准》等相 关标准和规范, 同时也要各地区教育部 门的配合和实施。例如, 组织不同的教师 团队和专家团队, 开展不同地区的调研, 提出不同修改意见和执行标准, 也需要 院校制定并落实具体实施方案。例如, 组织相关课程开发专家、行业领军人物、 企业一线员工、院校优秀教师等开展能 力本位课程开发建设, 并对各职业院校 进行经验交流和指导, 开展定期的组织 培训和学习。或建立一个相关教学能力 本位课程教学团队, 对不同地区职业院 校和行业 (企业) 进行调研, 分析和对应 不同地区产业需求, 开设相关课程建设;
也需要得到相关兄弟院校的大力支持和 实施, 提出修改意见和方案, 完善能力本 位课程的开发和建设。例如, 组织教师教 研活动, 开展学习等。也需要组织专业教 师参加相关培训, 增加课程建设和开发 的力度; 教师是能力本位课程具体的执 行者, 除了组织相关能力培训和学习以 外, 要求教师之间相互的沟通和交流, 组 织填写相关课程的项目计划书, 项目任 务点, 项目任务点评价方式, 评价的权重, 在评价和执行过程中, 怎样更好的引导 学生进步和完成项目任务书, 让学生从 中受到什么样的启发, 遇到相关问题会 做出一些弹性的调整, 以便能力本位课 程教育理念更好的发挥作用; 学生是能 力本位课程的参与者和受益者, 要求学 生要实际参与到每一个实际的项目中来, 在做的过程中, 不断的提出问题, 总结经 验, 及时的回馈相关信息。

室内艺术设计专业中, 从《建筑CAD》 这门课中来看, 比如学生在执行平面户 型图的绘制, 在绘制过程中, 老师首先下 发课程任务书, 并且老师根据任务要点, 讲授相关知识点 (如: 软件单位设置、标 注设置、图层设置、绘图习惯设置、图 形尺寸规范等), 学生根据老师操作的过 程来执行一个平面户型图绘制的项目任 务书。在绘制的过程中, 学生遇到问题, 可以不断的和同学之间交流, 也可以请 教老师指点。在最终的项目完成时, 根据 老师设置的项目任务书, 学生之间互评, 然后由学习兴趣小组长汇总, 并将汇总 结果告知老师, 老师根据汇总结果, 提出 相应的复习策略和课堂演练。

\section{4 可能存在的问题}

根据事物都有多面性的原理来看, 能力本位课程的开发, 也存在一些不足 和问题, 一些相同课程开发建设存在地 域上的差异性。比如, 以《室内装饰材料
与施工工艺》这门课程为例, 在泥工环节 上, 北方在保温处理上和南方地区不一 样, 北方要求加厚墙体, 以保持室内冬季 温暖, 而南方墙面部分装饰, 要防止夏季 西晒等不同。虽然能力本位课程的开发 和建设, 在不断的完善, 随着时间的推移, 新材料、新工艺、新机械和新技术的推 广, 对能力本位课程的开发带来了新的 问题。同时, 市场的不断变化, 也要求注 重课程项目任务书(任务点) 的更新和编 辑, 更新任务书可能会消耗很多时间。

\section{5 建设预期与展望}

能力本位课程开发建设下的人才培 养模式, 在不断的开发和建设, 为传统的 教学体系, 带来了新的参考范本, 也改变 了以往职业教育的教育模式, 比较容易 适应市场的需求和发展, 为我国职业教 育的改革和创新提供了很大的帮助, 在 未来的职业教育道路上, 需要更多的老 师团队和专家团队参与建设, 培养更多 为社会有用的人才。

\section{[参考文献]}

[1]苏冠元,刘宝云.能力本位课程开 发模式下的应用型二维动画本科人才培养 课程设置[J].教育与职业,2016,(16):96-97.

[2]王丽七.《焊接机器人技术》能 力本位的整体教学设计研究 [J].安徽职 业技术学院学报,2019,18(01):83-86.

[3] 杜沙沙.能力本位视域下高职老 师继续教育标准体系建设 [J]. 教育与职 业,2019,(09):68-75.

[4]戴文静.基于能力本位的高职教 育项目课程的构建路径 [J]. 职教通 讯,2019,(04):36-39.

[5]赵硕.能力本位教育:同质化还是异 质化? [N].中国科学报,2019-02-13(007).

\section{作者简介:}

钟鹤林(1988--), 男, 贵州仁怀人, 汉 族,讲师,硕士,研究方向: 环境艺术设计。 